\title{
A Case of Hemangioendothelioma of the External Auditory Canal
}

\author{
Sung Tae Seo ${ }^{1}$, Yong Won Lee ${ }^{1}$ and Yong Ho Park ${ }^{1,2}$ \\ ${ }^{1}$ Department of Otolaryngology-Head and Neck Surgery, ${ }^{2}$ Research Institute for Medical Sciences, \\ Chungnam National University College of Medicine, Daejeon, Korea
}

\section{외이도에 발생한 혈관내피종 1 예}

서성태 ${ }^{1} \cdot$ 이용원 ${ }^{1} \cdot$ 박용호 ${ }^{1,2}$

충남대학교 의과대학 이비인후과학교실, ${ }^{1}{ }^{2}$ 의학연구소 ${ }^{2}$

\author{
Received May 14,2010 \\ Revised June 16, 2010 \\ Accepted June 29, 2010 \\ Address for correspondence \\ Yong Ho Park, MD, PhD \\ Department of Otolaryngology-Head \\ and Neck Surgery, \\ Chungnam National University \\ College of Medicine, \\ 33 Munhwa-ro, Jung-gu, \\ Daejeon 301-721, Korea \\ Tel +82-42-280-7697 \\ Fax +82-42-253-4059 \\ E-mail parkyh@cnu.ac.kr
}

Hemangioendothelioma (HE) is a group of vascular neoplasms that may be considered benign or malignant in their activity. HE is differentiated by both its characteristic behavior and histologic appearance into benign (hemangioma) and malignant tumor (angiosarcoma). The tumor is characterized by neoplastic proliferation of epitheloid or histiocytic endothelial cells, and it commonly occurs in the soft tissues of extremities and liver, lung, but rarely in the external auditory canal. Surgical excision is the treatment of choice and the prognosis is generally good. The authors report, along with a review of related literatures, a 66 year-old male patient with HE of the right external auditory canal. Korean J Otorhinolaryngol-Head Neck Surg 2010;53:505-7

Key Words Hemangioendothelioma External auditory canal.

\section{서 론}

혈관내피종(Hemangioendothelioma, HE)은 내피세포 의 성장과 혈관의 군집으로 구성되는 혈관 기원의 드문 종 양이다. 병리조직학적 검사에서 세포이형성을 보이는 내피 세포에 의해 구분 되는 혈관의 풍부한 증식을 볼 수 있다. ${ }^{1)}$ 사지의 연부조직에 주로 발생하고 폐, 간, 비장 등의 내부 장기에서도 발견될 수 있다. 국내에서는 비중격에 발생한 증례가 보고되어 있지만 외이도의 혈관내피종은 아직 보고 된 바 없다.

조직학적으로 혈관육종(angiosarcoma)과 혈관종(hemagioma)의 중간 정도의 악성도를 보이며 대부분 외과적 절 제로 충분하고 예후는 양호한 편이다. ${ }^{2)}$

저자들은 66 세 남자에서 우측 외이도에 발생한 혈관내피 종 1 예를 치험하여 문헌 고찰과 함께 보고하는 바이다.

\section{증 례}

66세 남자 환자로 5개월 전부터 발생한 우측 종물을 주 소로 내원하였다. 과거력과 가족력의 특이 사항은 없었으며, 신체검사에서 우측 외이도 원위부 후상방에 약 $1.5 \times 1.5$ $\mathrm{cm}$ 크기의 단단하고 고정된 타원형의 종물이 촉지되었다 (Fig. 1).

측두골 전산화단층찰영에서 우측 외이도 원위부 후상방에 경계가 분명하고 비교적 균질한 형태로 조영증강되는 약 $1.6 \times 1.2 \mathrm{~cm}$ 크기의 타원형 결절이 관찰되었다(Fig. 2).

외이도에 발생한 양성 종양을 의심하여 수술을 계획하였 고, 전신마취하에 현미경을 사용한 후이개 접근법으로 약 $2 \mathrm{~mm}$ 정도의 절제연을 포함하여 종물을 일괴성으로 절제 하였다(Fig. 3).

조직 검사에서 다수의 혈관 통로와 경도의 세포 이형성 이 동반된 혈관세포들의 증식이 관찰되었으며(Fig. 4), 면 역화학조직염색에서 CD34과 Factor VIII RA에 양성 반응 
을 보여 혈관내피종으로 진단되었다(Fig. 5).

수술 4일 후 퇴원하였으며 수술소견과 조직병리학적 소 견을 고려하여 술 후 방사선 치료는 시행하지 않았다. 현재 환자는 약 5 년 동안 재발의 징후 없이 추적관찰 중이다.

\section{고 찰}

혈관내피종은 1903년 Mallory에 의해서 처음 보고되었

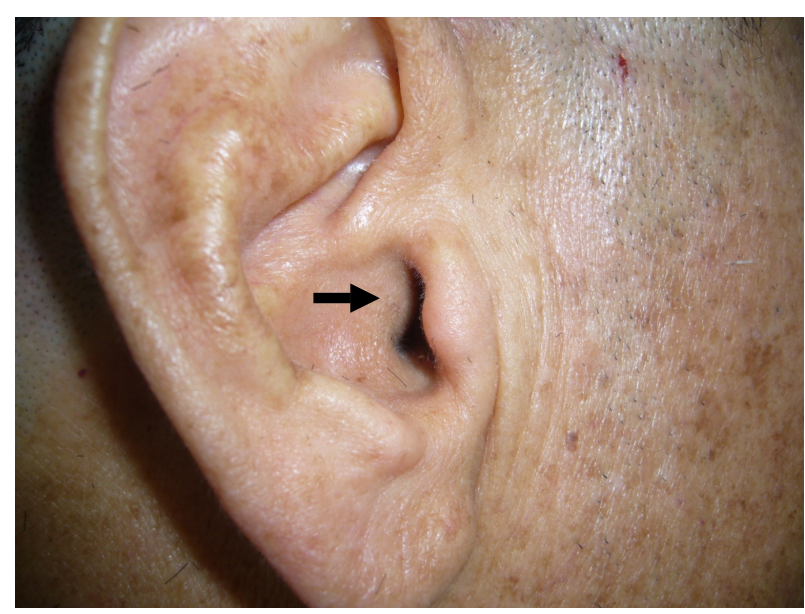

Fig. 1. Photograph showing $1.5 \times 1.5 \mathrm{~cm}$ sized firmly solid mass (arrow) in posterosuperior aspect of right external auditory canal.
으며 핵이형성증(nuclear dysplasia), 혈관의 문합성(anastomosis of vascular channels), 세포분열 모양에서 혈관 종과 혈관육종사이의 혈관 형성을 보이는 중등도의 악성도 를 가진 드문 혈관성 종양이다.,4)

맥관육종(angiosarcoma), 맥관내피종(angioendothelioma), 혈관육종(hemangiosarcoma), 혈관내피육종(hemangioendothelial sarcoma), 혈관아세포육아종(angioblastic

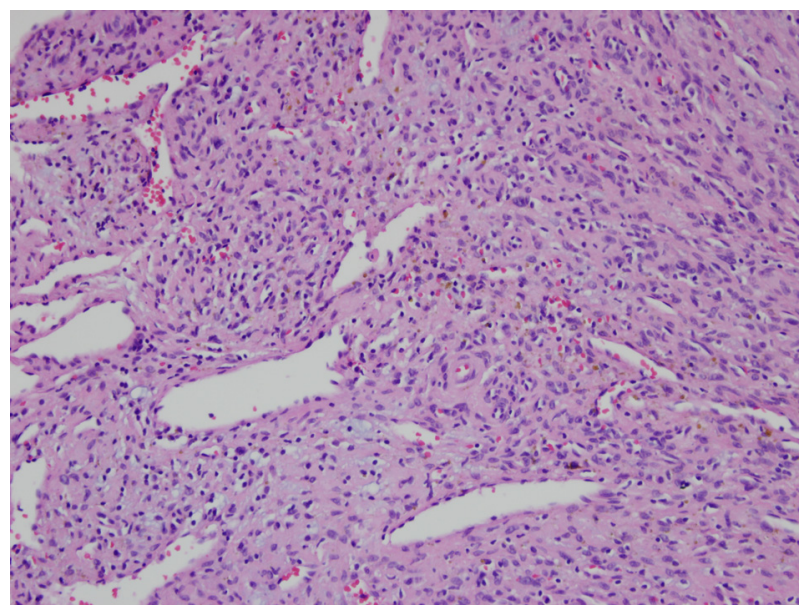

Fig. 4. Histopathologic findings demonstrate numerous vascular spaces lined by crowded endothelial cells with mild cytologic atypia (H\&E stain, $\times 200)$.
Fig. 2. Preoperative axial (A) and coronal (B) CT scans reveal about 1.6 $\times 1.2 \mathrm{~cm}$-sized well-defined ovoid shaped nodule (arrow) in posterosuperior aspect of right external auditory canal.
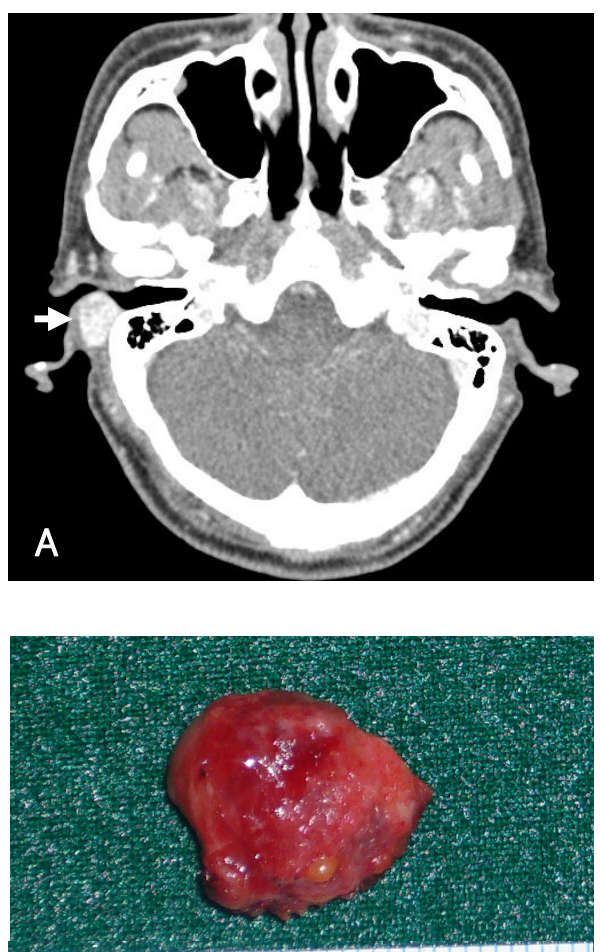

A

Fig. 3. Excised tumor mass, which is reddish and soft ovoid (A and $B)$.
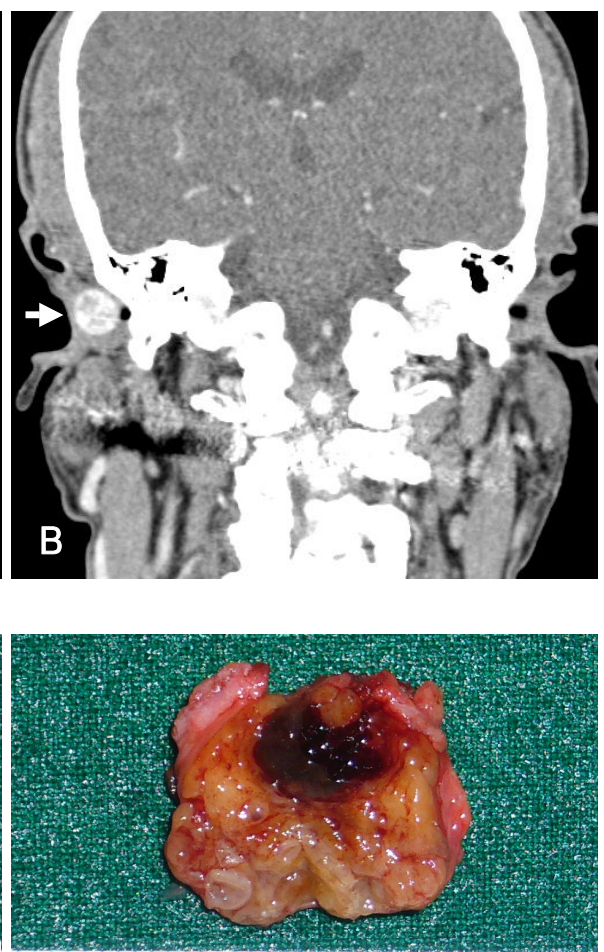

B 

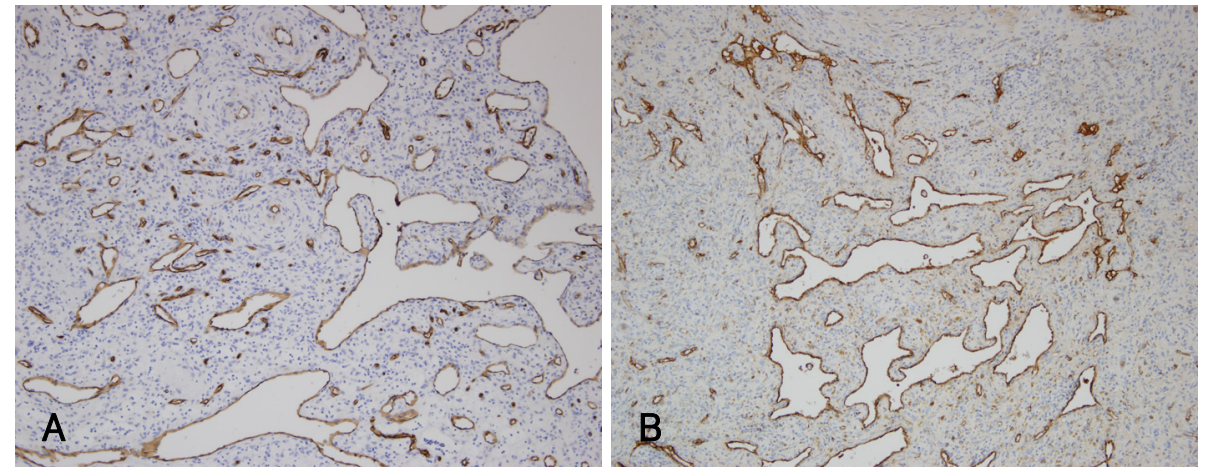

Fig. 5. Immunohistochemical study of the tumor cells shows positive reaction of CD34 (A) and Factor VIII Antigen (B), which is a marker for endothelial cells.

sarcoma) 등 여러 질환과 혼용되었으며 최근에는 이러한 종양들을 모두 혈관내피종으로 명명하는 추세이다. ${ }^{5,6)}$

발병률은 남자와 여자에서 차이가 없으며 소아에서는 거 의 발생하지 않는 것으로 알려져 있으며, 주로 사지의 연부 조직이나 폐, 간 등에 많이 발생한다. 두경부의 피부, 구강 내 점막과 입술, 비강 등에서도 발생할 수 있지만, 본 증례와 같이 외이도에서 발생하는 경우는 아직 보고된 바 없다. ${ }^{7,8)}$

혈관내피종은 임상적으로는 진단하기 어려우며 조직병리 학적 진단이 필수적이다. 많은 수의 방추모양 내피세포들로 둘러 쌓여진 작은 공간에 의한 혈관 형성이 관찰되며, 세포 의 괴사나 세포분열모습은 거의 관찰 할 수 없다. 핵의 모양 은 일정하여 다형태성을 보이지 않으며, 세포질은 아주 적 고 공포(vacuole)가 있는 경우는 매우 드물다. ${ }^{9,10)}$

면역조직화학적염색에서는 $\mathrm{CD} 31, \mathrm{CD} 34$, vimentin 그리 고 Factor VIII RA와 Ulex europeus에 양성반응을 보이 면 내피세포 기원의 종양임을 확인 할 수 있어 진단에 도움 이 된다. ${ }^{11)}$

혈관내피종의 치료는 외과적 절제가 가장 중요하며, 조직 학적 분화도에 따라 술 후 방사선치료를 시행할 수 있다. 수 술적 치료가 불가능할 경우에는 국소 방사선치료와 $\alpha-$ interferon(IFN)을 이용한 치료가 도움이 될 수 있으며 cyclophosphamide 등을 사용하는 항암화학요법은 효과가 없는 것으로 보고되어 있다. ${ }^{12)}$

일반적으로 예후는 양호한 것으로 알려져 있지만 조직학 적 분류에 따라 차이가 있다고 보고하기도 하였다. 혈관 형 성 정도, 종양세포의 다형성성, 세포분열양상에 따라 3 단 계로 분류하였으며 단계가 높아질수록 악성에 가까운 소 견을 보여 생존율이 각각 $95 \%, 63 \%$ 그리고 $20 \%$ 로 차이
를 보인다고 하였다. ${ }^{6)}$

수술 후 재발은 약 $13 \%$ 정도로 보고되고 있으며 본 증례 의 경우에는 수술 후 5년이 지난 지금까지 재발 없이 추적 관찰 중이다. ${ }^{12)}$

\section{REFERENCES}

1) Joo M, Lee GJ, Koh YC. Park YK. Hemangioendothelioma of the sphenoid bone: a case report. J Korean Med Sci 2001;16 (2) :241-4.

2) Brackmann DE, Bartels LJ. Rare tumors of the cerebellopntine angle. Otolaryngol Head Neck Surg 1980;88 (5) :555-9.

3) Chan JK, Frizzera G, Fletcher CD, Rosai J. Primary vascular tumors of lymph nodes other than Kaposi's sarcoma. Analysis of 39 cases and delineation of two new entities. Am J Surg Pathol 1992;16 (4):335-50.

4) Enzinger FM, Weiss SW. Hemangioendothelioma: vascular tumors of intermediate malignancy. In: Enzinger FM, Weiss SW, editors. Soft tissue tumors. 3rd ed. St. Louis: Mosby-Year Book;1995. p.627-40.

5) Hamlat A, Casallo-Quilliano C, Saikali S, Lesimple T, Brassier G. Epithelioid hemangioendothelioma of the infundibular-hypothalamic region: case report and literature review. J Neurooncology 2004;67 (3): 361-6.

6) Unni KK. Dahlin's bone tumors: General aspect and data on $11087 \mathrm{ca}-$ ses. 5th ed. Philadelphia: Lippincott-Raven;1996. p.317-28.

7) Weiss SW, Ishak KG, Dail DH, Sweet DE, Enzinger FM. Epithelioid hemangioendothelioma and related lesions. Semin Diagn Pathol 1986; $3(4): 259-87$.

8) Flaitz CM, McDaniel RK, Mackay B, Kennady MC, Luna MA, Hicks MJ. Primary intraoral epithelioid hemangioendothelioma presenting in childhood: review of the literature and case report. Ultrastruct Pathol 1995;19 (4) :275-9.

9) Weiss SW, Enzinger FM. Epithelioid hemangioendothelioma: a vascular tumor often mistaken for a carcinoma. Cancer 1982;50 (5):97081.

10) Enzinger FM, Weiss SW. Soft tissue tumors. $2^{\text {rd }}$ ed. St. Louis: Mosby-Year Book;1988. p.533-44.

11) Flanagan JC, Mauriello JA Jr. Management of lacrimal sac tumors. Adv Ophthalmic Plast Reconstr Surg 1984;3:399-408.

12) Wold LE, Unni KK, Beabout JW, Ivins JC, Bruckman JE, Dahlin DC. Hemangioendothelial sarcoma of bone. Am J Surg Pathol 1982;6(1): $59-70$. 